\section{LEXICAL ASPECT AND THE USE OF SIMPLE PAST TENSE BY THAI LEARNERS OF ENGLISH ${ }^{1}$}

\section{Suriya Sriphrom ${ }^{2}$ \\ Theeraporn Ratitamkul $^{3}$}

\begin{abstract}
This cross-sectional study investigated the use of the simple past tense form by twenty Thai learners of English at two levels of proficiency. A cloze test developed by Ayoun and Salaberry (2008) was adopted. The findings showed that the learners in the high proficiency group used the past tense form more accurately than the learners in the low proficiency group. When verbs were categorized according to lexical aspect, both groups of learners were found to use the simple past tense form most often with telic events as well as with states. This did not correspond to the prediction of the Aspect Hypothesis, which asserts that low-level learners tend to use the simple past tense form with telic events first. The distributional bias in the input could account for the pattern found in this study.
\end{abstract}

\footnotetext{
${ }^{1}$ This paper is a part of the doctoral dissertation entitled Development of the relationship between tense forms and temporal-aspectual meanings in English in relating past events by Thai learners ${ }^{2} \mathrm{Ph}$.D. candidate, Department of Linguistics, Faculty of Arts, Chulalongkorn University, Bangkok, Thailand.

${ }^{3}$ Assistant Professor, Department of Linguistics, Faculty of Arts, Chulalongkorn University, Bangkok, Thailand.
}

\section{Introduction}

English tenses generally pose difficulty for learners. Several studies with Thai learners of English showed that one of the most common errors they made was the use of tenses. For example, in one of the earliest studies of Thai learners of English, Suwattee (1971) examined students' difficulties in using the English verb system. She analyzed 152 English entrance examination papers written by Thai students and found that the error count on the use of tenses showed the highest frequency. Malayamonthon (1998) also reported a similar result. He asked 137 Thai upper secondary students of a public school to write a composition after watching the animated film 'Cinderella'. $\mathrm{He}$ investigated errors drawn from 30 English compositions. Results showed that the errors on tense usage were most frequent $(30.78 \%)$. As the inaccurate use of tenses is a highly frequent mistake, some studies have analyzed the causes of errors among Thai learners. Noochoochai (1978) and Tawilapakul (2003), for example, claimed that transfer was one of the causes. Noochoochai analyzed tense errors in 200 compositions written by advanced English students at the university level. He found that the percentages of incorrect usage of the simple future tense form and simple past tense form were higher than the percentages of correct usage. The students' most frequent mistake was incorrectly replacing simple past tense forms with base or bare verb forms. Tawilapakul analyzed a Thai-English translation test done by 75 first-year undergraduate students to investigate the impact of the use of time markers in Thai. It was found that some time markers in Thai gave a positive impact on the use of English tenses. For example, mîa-rew-rew-níi 'recently' guided the students to use past tense 
correctly and rew-rew-níi 'soon' guided them to use future tense correctly. However, time marker such as 'at the age of...' had a negative impact. In the sentence at the age of sixteen, he was running a family business, past progressive tense was expected. A few students $(2.67 \%)$ used the correct tense. She concluded that time markers, as a linguistic factor, played a role in tense use. Both studies ascribed such errors to the fact that Thai has only one verb form which does not change according to temporal reference, thus concluding that some errors in tense use resulted from language transfer. The above studies demonstrated that Thai students had difficulty in using English tenses. However, most of the previous studies, except that of Tawilapakul, did not investigate other linguistic factors which could account for correct and incorrect use of English tenses by Thai learners.

Difficulty in acquiring tenses in English may stem from the fact that Thai is an isolating language with little use of inflectional morphology. However, native speakers of languages with inflectional morphology were found to encounter similar difficulty. Klein (1995) conducted research on the acquisition of English temporality. He collected data from four Italian adult learners over a period of two and a half years. His Italian informants showed that, at the beginning, the verbs used were not modified for tense or aspect and they normally had the form of the bare stem. Later on, some informants gradually moved in the direction of the target language. Despite the fact that Italian and English are both inflectional languages, the Italian learners of English failed to use past tense forms correctly and consistently at an early stage of learning. This shows that language learners crosslinguistically encounter difficulty in tense use.

In the following section, the Aspect Hypothesis is reviewed as an approach that uses semantic categories of lexical aspects as a linguistic factor accounting for developmental patterns of tense and aspect acquisition.

\section{The Aspect Hypothesis}

To encode time in English, tense and aspect are obligatory. Tense is a grammaticalized expression of location in time (Comrie 1985: 9). Lyons (1995: 318) defined tense as the category which results from the grammaticalization of incidental (definite) deictic temporal reference. Klein (2010:43) mentioned terminological confusions of tense and showed that such technical terms can refer to, firstly, the grammatical notion; secondly, a particular form; thirdly, a particular function or meaning. In this study, 'tense form' and 'tense meaning' are used to avoid confusion. For example, in They went to school yesterday, the simple past tense form went is used to convey simple past tense meaning. In They go to school yesterday, however, the simple present tense form $\mathrm{go}^{4}$ is used to express simple past tense meaning.

According to Comrie (1976:3), aspects are different ways of viewing the internal temporal constituency of a situation. For example, in John was reading when I entered, the first verb presents the background to some event, while that event itself is introduced by the second verb. The second verb presents the totality of the situation referred to without reference to its internal temporal

\footnotetext{
${ }^{4}$ The form $g o$ can also be regarded as a bare form, which is a form with no inflection.
} 
constituency. Lyons (1995: 322) defined aspect as the category which results from the grammaticalization of the internal temporal constituency (or contour) of situations (actions, events, states, etc.). Like 'tense', the term 'aspect' is also ambiguous. According to Smith (1997: 1), the term 'aspect' refers to grammaticized viewpoints such as the perfective and imperfective aspects. As this type of aspect is conveyed morphologically, it is known as 'grammatical aspect'. In addition, the term 'aspect' also refers to temporal properties of situations, or situation types which concern the inherent semantics of verbs. This type of aspect is therefore called 'lexical aspect'. Table 1 below shows four situation types or lexical aspects proposed by Vendler (1967).

Table 1 Feature analysis of the four verb classes (adapted from Shirai and Andersen 1995)

\begin{tabular}{|l|c|c|c|c|}
\hline & STATE & ACTIVITY & $\begin{array}{c}\text { ACCOM- } \\
\text { PLISHMENT }\end{array}$ & $\begin{array}{c}\text { ACHIEVE- } \\
\text { MENT }\end{array}$ \\
\hline Punctual & - & - & - & + \\
\hline Telic & - & - & + & + \\
\hline Dynamic & - & + & + & + \\
\hline
\end{tabular}

Vendler categorized verbs according to their internal temporal features. The internal temporal features are dynamicity, telicity and punctuality. Dynamicity distinguishes all other predicates from states. States are not interruptible. Examples of states include seem, know, need, want and be (as in be tall, be big, be green) (Bardovi-Harlig 2000). Dynamic verbs can be divided into two main groups according to telicity. Telicity is an internal temporal feature which pertains to an endpoint. Dynamic verbs which have duration but have no specific endpoint are classified as activities. For example, John is running and I studied all week. More examples of activities are play, dance, and walk. Dynamic verbs which have a specific endpoint are telic verbs. Among telic verbs, two subdivisions are found according to the last internal temporal feature, punctuality. Telic verbs which take place instantaneously are called achievements. Achievements capture the beginning or end of an action (Mourelatos 1981) and can be thought of as reduced to a point (Andersen 1991). Examples of achievements are begin, end, arrive, leave, recognize, die, fall asleep and reach the summit. The other type of telic verbs is accomplishment. Accomplishments have an endpoint like achievements but do not take place instantaneously. They have some duration like activities. Examples of accomplishments include run a mile, make a chair, build a house, etc.

Lexical aspect was claimed to play an important role in tense and aspect acquisition. Brown (1973) and also Bloom, Lifter and Hafitz (1980) found that children's English past tense marking is not distributed evenly to all past tense contexts, but appears to be selectively attached to instantaneous, change of state verbs that denote clear end-results (as cited in Shirai 2010). Such trends have also been found in second language acquisition. Andersen (1991) noticed that learners of English as a second language begin with verbs with no inflection, where all verbs appear in the base or bare form. When these learners start using past inflections, the inflections are limited to punctual verbs, which are momentary in duration, e.g., recognize someone or win the race. Subsequently, past inflections are used with other verb classes. Andersen assumed that the semantics of events or inherent lexical aspects of verbs play a role in the emergence of tense and aspect marking in second language acquisition. 
Due to associations between tense-aspect marking and lexical aspect, Andersen and Shirai (1994) proposed the Aspect Hypothesis to account for the distribution of tense marking in the process of acquiring both native languages and second languages:

1. Learners first use past marking (e.g., in English) or perfective marking (e.g., in Chinese and Spanish) on achievement and accomplishment verbs, eventually extending their use to activity and stative verbs.

2. In languages that encode the perfective/imperfective distinction, imperfective past appears later in learning than perfective past, and imperfective past marking begins with stative verbs and activity verbs, then extending to accomplishment and achievement verbs.

3. In languages that have progressive aspect, progressive marking begins with activity verbs, then extending to accomplishment or achievement verbs.

4. Progressive markings are not incorrectly overextended to stative verbs.

(Shirai 2010: 173)

Shirai (2010) reported that the Aspect Hypothesis has been extensively investigated cross-linguistically in second language acquisition such as in Spanish (Andersen 1991), English (Robinson 1990; Bardovi-Harlig and Reynolds 1995), French (Bardovi-Harlig and Bergström 1996), Italian (Giacalone Ramat 1995), Japanese (Shirai and Kurono 1998), and Korean (Lee and Kim 2007), among others. However, there is mixed evidence concerning the role of lexical aspect in the acquisition of tense forms by second language learners.
The Aspect Hypothesis was supported by, for instance, Bardovi-Harlig and Reynolds (1995), Collins (2002) and Collins (2004). Bardovi-Harlig and Reynolds (1995) conducted a cross-sectional study to investigate the acquisition of the simple past tense form by 182 adult learners at six levels of proficiency. The results showed that, at the lowest levels of proficiency, students exhibited a high rate of usage of simple past tense form for achievement and accomplishment verbs and a relatively low rate of appropriate use of the simple past tense form with activity and state verbs. This indicates that lexical aspect influences the use of simple past tense form as predicted by the Aspect Hypothesis. Collins (2002) conducted two cross-sectional studies to investigate the role of lexical aspect in adult Francophone ESL learners' use of tense-aspect markers in past contexts. The learners were significantly more successful in using the simple past tense form with telic verbs. In addition, Collins (2004) also supported the predictions of the Aspect Hypothesis. She compared the acquisition of tense-aspect morphology among 139 Japanese- and French-speaking learners of English and found that, for both L1 groups, the marking of the simple past tense form spread from achievements and accomplishments, which are telic verbs, to activities and states.

Despite some supportive results, the Aspect Hypothesis did not seem to hold in some studies. Housen (2000) conducted a longitudinal study of the development of tense-aspect in L2 English. His Dutchspeaking informant showed development of past/perfect tense morphology which contradicted the predictions of the Aspect Hypothesis. That is, although past/perfect morphology did occur mainly with achievements at the beginning, it also 
occurred frequently with states. Ayoun and Salaberry (2008) also reported findings which conflict with the Aspect Hypothesis. In their study, 21 high school French speakers learning English in France completed two written elicitation tasks: a personal narrative and a cloze task. In the narrative task, states were marked with the simple past tense form more consistently than telic events. However, the cloze task showed no such difference in the use of the simple past tense form.

Since it is not clear if lexical aspect influences Thai learners of English at different levels of proficiency, our study aims to investigate how Thai learners use the simple past tense form in English and whether the patterns observed correspond to the Aspect Hypothesis.

\section{Data collection}

The present study seeks to answer two research questions. Firstly, do learners in the high proficiency group tend to use simple past tense form more correctly than learners in the low proficiency group? Secondly, do learners in the high proficiency group use the simple past tense form with verbs of all aspectual classes while learners in the low proficiency group use the simple past tense form with telic verbs more frequently than with verbs in other aspectual classes? As for the first research question, we predicted that learners in the high proficiency group would use the simple past tense form more correctly than learners in the low proficiency group. Regarding the second research question, we predicted that learners in the high proficiency group would use the simple past tense form with verbs of all aspectual classes while learners in the low proficiency group would use the simple past tense form with telic verbs more frequently than with verbs in other aspectual classes.

\subsection{Participants}

Two groups of undergraduate students at Chulalongkorn University were chosen to participate in our study to represent two stages of development. CU-TEP ${ }^{5}$ scores were used as a criterion to distinguish those two stages of development. Ten participants whose scores were between 351 and 450 were considered very limited to moderate users (hereafter, the low proficiency group). These students were from the Faculty of Commerce and Accountancy, the Faculty of Science, and the Office of the Commission on Agricultural Resource Education (OCARE). The other ten students with CU-TEP scores between 501 and 600 were considered competent to good users (hereafter, the high proficiency group). These students were from the Faculty of Commerce and Accountancy, Faculty of Communication Arts, Faculty of Law and Faculty of Science. All participants took the CU-TEP examination within one year of the time they participated in the experiment.

\subsection{Material}

The cloze test used by Ayoun and Salaberry (2008) was adopted for use in this study. The text for this cloze test was one page long with 59 blanks. A verb phrase in an infinitive form was given in a

${ }^{5}$ CU-TEP (Chulalongkorn University Test of English Proficiency) is a standardized test of English proficiency offered by Chulalongkorn University. The test comprises listening, reading and writing. The highest range of scores is $>700$, which is considered as the level of an 'expert user', and the lowest range of scores is $<400$, which is considered as the level of a 'very limited user'. 
bracket after each blank. According to a control group of 18 native speakers of English in Ayoun and Salaberry's study, 48 blanks should be filled with verbs in the simple past tense form (i.e., more than half of the native speakers in the original study chose the simple past tense form as appropriate answers to these questions). Therefore, the verb phrases in these 48 blanks were considered as the verb phrases denoting past-time events and were the focus of this study. These verb phrases were classified into three categories according to lexical aspect. There were 15 states, 6 activities and 27 telic events. In this study, as well as in that of Ayoun and Salaberry, telic events refer to both achievements and accomplishments. This cloze test was selected because it targeted the use of simple past tense and the verbs in the test were distributed across lexical aspectual categories to test the Aspect Hypothesis. Moreover, using this test enabled us to compare our results with those in previous studies. The verbs in the cloze test are listed in Appendix A, and the cloze test is available in Appendix B.

\subsection{Procedure}

The participants were asked to read the cloze test and fill in the blanks with correct tense forms within the period of one hour.

\subsection{Coding of answers}

Following Ayoun and Salaberry (2008), responses were grouped into one of the following five categories: incorrect, correct, partially correct, correct alternative, and missing. The responses labeled "incorrect" refer to the case when a non-target tense form was used. For example, if tell was used instead of told, it would be marked incorrect. The response was considered "correct" when the target tense was used with the appropriate morphological form and inflection. "Partially correct" refers to the case when the target tense was used but with an inappropriate morphological form and/or inflection, for instance, when telled was used instead of told. The fourth category was "correct alternative". This means an appropriate tense other than the target tense was used. The category "correct alternative" was based on answers given by the control group of 18 native speakers of English in Ayoun and Salaberry (2008). If participants gave no answer or left the slot blank, this slot was considered as "missing".

\section{Results and analyses}

The results of the high proficiency group and those of the low proficiency group were compared in terms of accuracy. The high proficiency group did better on the cloze test than the low proficiency group. Table 2 shows the types of answers given by the two groups. There were no answers in the categories "correct alternative" and "missing". The high proficiency group gave a larger number of correct answers than the low proficiency group. The number of correct answers in the high proficiency group was $388 \quad(80.83 \%)$ whereas 287 correct answers (59.79\%) were provided by the low proficiency group. Moreover, 8 partially correct answers $(1.67 \%)$ were found in the high proficiency group whereas 20 partially correct answers $(4.17 \%)$ were found in the low proficiency group. Overall, the high proficiency group had significantly more correct and partially correct answers than the low proficiency group $(t(18)=2.62, p$ $<0.01)$. This result showed that the high proficiency students performed the task of correctly using the simple past tense form better than the low proficiency students. 
Table 2 Types of answers according to correctness

\begin{tabular}{|l|c|c|c|c|}
\hline \multirow{2}{*}{$\begin{array}{c}\text { answer } \\
\text { type }\end{array}$} & \multicolumn{2}{c|}{$\begin{array}{c}\text { low } \\
\text { proficiency }\end{array}$} & \multicolumn{2}{c|}{$\begin{array}{c}\text { high } \\
\text { proficiency }\end{array}$} \\
\cline { 2 - 5 } & token & $\%$ & token & $\%$ \\
\hline $\begin{array}{l}\text { correct } \\
\text { partially } \\
\text { correct }\end{array}$ & 287 & 59.79 & 388 & 80.83 \\
incorrect & 173 & 4.17 & 8 & 1.67 \\
\hline total & 480 & 100 & 480 & 100 \\
\hline
\end{tabular}

In terms of the frequency of tense forms used, Table 3 shows all tense forms found in the answers of each proficiency group. The most frequently used tense form in both proficiency groups was the simple past tense form, which accounted for more than half of the total answers. Three hundred and seven simple past tense forms $(63.96 \%)$ were found in the low proficiency group and 396 simple past tense forms $(82.50 \%)$ were found in the high proficiency group. The second most frequently used form in the low proficiency group was the bare form and simple present tense form (118 tokens, $24.58 \%$ ). However, the high proficiency group seldom used the bare form or simple present tense form (20 tokens, 4.17\%). They sometimes used the past progressive tense form as an alternative to the simple past tense form (35 tokens, 7.29\%). Nonetheless, the number of past progressive tense forms was dramatically smaller than that of simple past tense forms.

In addition to the frequency of simple past tense forms, this study is interested in the distribution of simple past tense forms according to the three classes of verbs (state, activity and telic). Table 4 shows the number of simple past tense forms used according to the three lexical aspects.
In the low proficiency group, the proportion of simple past tense form for state verbs was $68 \%$ (102 out of 150 tokens) while the proportion of this tense form for state verbs in the high proficiency group was $88 \%$ (132 out of 150 tokens). Regarding activity verbs, the simple past tense form was used $46.67 \%$ (28 out of 60 tokens) in the low proficiency group and $56.67 \%$ (34 out of 60 tokens) in the high proficiency group. As for telic verbs, the simple past tense form was used $65.56 \%$ (177 out of 270 tokens) in the low proficiency group and $85.19 \%$ (230 out of 270 tokens) in the high proficiency group.

Figure 1 shows the pattern of distribution of simple past tense forms according to lexical aspects in both groups. The patterns in the two groups were similar in that state verbs had the highest proportion of simple past tense forms, followed by telic and activity verbs, respectively. Following the Aspect Hypothesis, the low proficiency learners were expected to use the simple past tense form with telic verbs more frequently than with verbs of other aspectual classes and the high proficiency learners should be able to use simple past tense form evenly across the three lexical aspects.

To test the influence of lexical aspect on the use of simple past tense forms, a $2 \times 3$ ANOVA was conducted with proficiency level (low and high) as a between-subject factor and lexical aspect (state, activity and telic) as a within-subject factor. It was found that there was a significant effect of proficiency level $[F(1,18)=4.56, p<$ $0.05]$ and lexical aspect $[F(2,36)=21, p$ $<0.0001]$. There was no significant interaction between proficiency level and lexical aspect $[F(2,36)=1, p=0.38]$. 
Table 3 Tense forms found in each proficiency group

\begin{tabular}{|l|c|c|c|c|}
\hline \multirow{2}{*}{ Tense form } & \multicolumn{2}{c|}{ low proficiency } & \multicolumn{2}{c|}{ high proficiency } \\
\cline { 2 - 5 } & token & $\%$ & token & $\%$ \\
\hline bare form and simple present $^{6}$ & 118 & 24.58 & 20 & 4.17 \\
present progressive & 2 & 0.42 & 0 & 0.00 \\
present perfect & 0 & 0.00 & 6 & 1.25 \\
simple past & 307 & 63.96 & 396 & 82.5 \\
past progressive & 11 & 2.29 & 35 & 7.29 \\
past perfect & 24 & 5.00 & 15 & 3.13 \\
past perfect progressive & 1 & 0.21 & 0 & 0.00 \\
future in the past & 1 & 0.21 & 0 & 0.00 \\
unidentifiable & 16 & 3.33 & 8 & 1.67 \\
\hline total & 480 & 100 & 480 & 100 \\
\hline
\end{tabular}

Table 4 Distribution of simple past tense forms according to lexical aspects

\begin{tabular}{|l|c|c|c|c|c|c|}
\hline \multirow{2}{*}{} & \multicolumn{2}{|c|}{ State $(\mathrm{N}=150)$} & \multicolumn{2}{c|}{ Activity $(\mathrm{N}=60)$} & \multicolumn{2}{c|}{ Telic $(\mathrm{N}=270)$} \\
\cline { 2 - 7 } & token & $\%$ & token & $\%$ & token & $\%$ \\
\hline low proficiency & 102 & 68 & 28 & 46.67 & 177 & 65.56 \\
\hline high proficiency & 132 & 88 & 34 & 56.67 & 230 & 85.19 \\
\hline
\end{tabular}

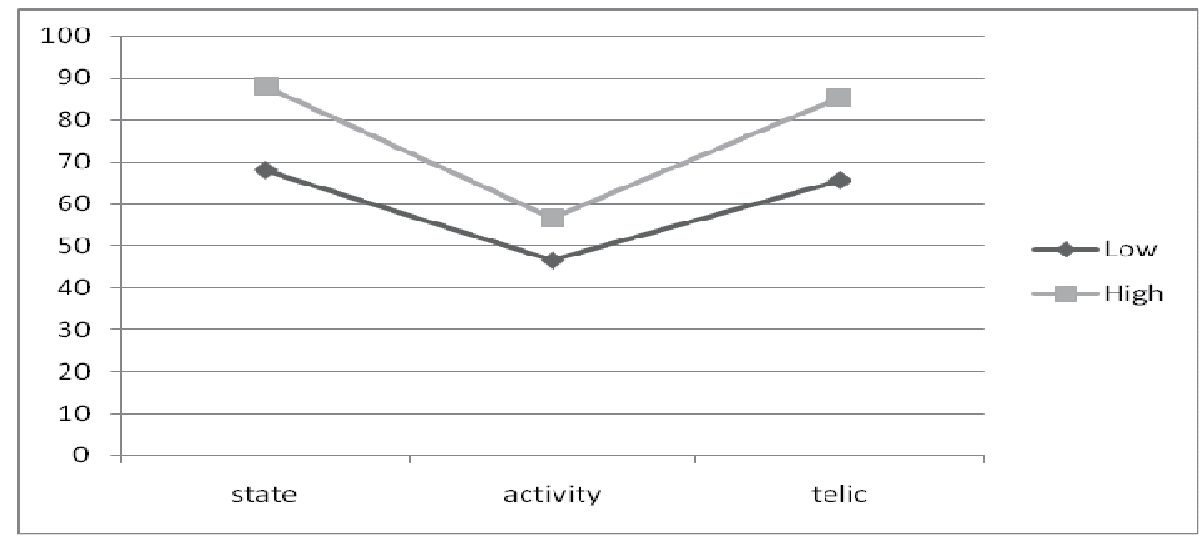

Figure 1 Distribution of simple past tense forms according to lexical aspects

\footnotetext{
${ }^{6}$ The bare form and simple present form were grouped together because they were indistinguishable in many cases (see Footnote 4).
} 
As reported earlier, the high proficiency group used simple past tense forms more frequently than the low proficiency group across all lexical aspects. A main effect of lexical aspect further revealed that the lexical aspectual class played a role in participants' choice of simple past tense form. A closer examination showed that in the low proficiency group, simple past tense forms occurred with state verbs more frequently than with activity verbs $(t(9)=$ $2.78, p=0.01)$. They were also used with telic verbs more often than with activity verbs $(t(9)=2.41, p=0.02)$. However, there was no difference between states and telics $(t(9)=0.42, p=0.34)$. The same pattern was observed for the high proficiency group. State verbs had a significantly higher proportion of simple past tense forms than activity verbs $(t(9)=$ $4.54, p<0.001)$, and so did telic verbs $(t$ $(9)=4.46, p<0.001)$. State verbs and telic verbs, as was similar in the low proficiency group, did not differ $(t(9)=$ $0.88, p=0.2$ ).

\section{Discussion}

This study aims to address two research questions. The first question focuses on the development of the correct use of simple past tense forms. The second question deals with the influence of lexical aspect on the choice of the simple past tense form. Regarding the first question, we predicted that Thai learners of English with high proficiency, who represented a later stage of development would use simple past tense form more accurately than those with low proficiency, who represented an earlier stage. Our finding supported this prediction. The high proficiency group used simple past tense form more accurately and consistently than the low proficiency group. The high proficiency group's use of tense-aspect morphology was therefore more systematic and conformed more closely to native speakers' norms than that of the low proficiency group. However, it should also be noted that the simple past tense form ranked the highest among all tense forms in both proficiency groups $(63.96 \%$ in the low proficiency group and $82.5 \%$ in the high proficiency group). This indicates that both the high and the low proficiency groups were sensitive to the marking of past-time events in English to a certain degree.

Despite the fact that the past tense form was required, the low proficiency group supplied a rather high number of bare forms and simple present tense forms (118 out of 480 tokens, $24.58 \%$ ). We further investigated whether regularity of simple past tense forms had an effect on simple past tense marking. When we examined the marking of simple past morphology and regularity of verb forms, we found that there was no difference in the use of simple past tense morphology between regular and irregular verbs in the high proficiency group $(t(9)=0.16, p=0.88)$. However, students in the low proficiency group provided a larger number of simple past tense forms with irregular verbs than with regular verbs $(t(9)=2.36, p=0.04)$. This suggests that low proficiency learners' choice of simple past tense form could be influenced by regularity of verb forms. The fact that irregularity favors past tense marking has been found in previous SLA studies. Wolfram and Hatfield (1984) investigated past tense marking in two groups of Vietnamese learners of English who differed in their length of residency in an English-speaking environment. It was found that, in both groups, regular forms of the past tense were less likely to be marked for tense than irregular forms. Wolfram (1985) attributed this pattern of 
systematic variability to a "principle of perceptual saliency". He claimed that the more distant phonetically the past tense form is from the present tense form, the more likely it is to be marked for past tense. Housen (2002) also found that regular past tense forms appeared later than these irregular counterparts. She followed Francis and Kucera's (1982) explanation pertaining to the general trend among native speakers of English. That is, regular past tense forms have high type frequency but low token frequency while the reverse holds for irregular past tense forms. It is possible that our low proficiency learners were influenced by perceptual saliency and token frequency of irregular past tense forms, thus producing more simple past tense forms with irregular verbs than with regular verbs.

Our second research question focused on the influence of lexical aspect on the use of simple past tense forms. Based on the Aspect Hypothesis, we predicted that the low proficiency learners would use simple past tense form more often with telic verbs than with verbs in other aspectual classes while the high proficiency learners would use simple past tense form regardless of lexical aspect. Our results showed otherwise. In both groups, the proportions of simple past tense forms were not different in state verbs and telic verbs. The finding that Thai learners were more successful at marking the simple past tense form with states and telics than activities is similar to Housen's (2000) and Ayoun and Salabery's (2008) results. Housen's (2000) data from interviews including personal and elicited narratives revealed that, at early stages, simple past tense form frequently occurred with achievements and states. In Ayoun and Salaberry (2008), the data from the cloze test showed that states and telics were marked with simple past tense form more consistently than activities, although their data from the narrative task revealed that state verbs were marked with past tense morphology more consistently than telic verbs. The nature of the tasks therefore seems to affect participants' performance. Ayoun and Salaberry (2008) speculated that a cloze test might allow for the monitoring of language form, which would explain why the distribution of simple past tense forms with states did not follow the prediction of the Aspect Hypothesis. According to Bonilla (2008), studies that used a personal narrative task supported the Aspect Hypothesis. Shirai (2010) also found that when participants were allowed planning time, results were consistent with the Aspect Hypothesis.

To account for the patterns in the high and low proficiency groups, we followed Ayoun and Salaberry's (2008) explanation pertaining to distributional bias in the input. Ayoun and Salaberry observed that while states tend to be consistently marked with simple past only (e.g., I was happy as opposed to $* I$ was being happy), telics and activities can occur with both simple past tense form and past progressive tense form. An example from the cloze test: $a$ few minutes later, as I was closing the curtains from my living room window, I caught a glimpse of that old man. The underlined verbs were correct forms. Both 'close' and 'catch' are telic verbs. However, according to the context and the intended meaning, different tense forms are used for these two verbs in the same aspectual class. In order to express an extended duration of the event, the past progressive form was closing was used whereas the simple past tense form caught showed an event of a short or no duration. Activity events can also take both simple past tense form and past progressive tense 
form. Due to this distributional bias in the input, learners may find it common to mark state verbs with the simple past tense form. It is possible that the Thai learners in our study were led by the distributional bias in the input, thus producing simple past tense forms with state verbs. At the same time, the association between telic events and simple past tense meaning as proposed by the Aspect Hypothesis also boosted the use of simple past tense forms with telic verbs.

Unlike our prediction, the high proficiency group did not use simple past tense form evenly with verbs in all lexical aspects. Although the proportions of simple past tense form were higher in the high proficiency group than in the low proficiency group for all aspectual categories, the two groups shared the same pattern of simple past tense form distribution. This could be due to the fact that the high proficiency learners in our study were still influenced by the lexical aspect of predicates and could not yet reach the level of native speakers.

\section{Conclusion}

Our findings demonstrate that proficiency level plays an important role in the accurate use of simple past tense forms. The learners of high proficiency tended to use accurate simple past tense forms more frequently than the low proficiency group. Moreover, lexical aspect influences the use of simple past tense forms in both groups. Nonetheless, contrary to the Aspect Hypothesis, both groups of learners were more successful in using simple past tense forms with states and telic events than with activities. An explanation draws on a distributional bias in the input. The results of the study imply that Thai learners of English struggle most with activities. In terms of classroom instruction, learners could be exposed to more input or more examples of activities in simple past tense form. Finally, it will be important in future research to obtain data from different types of tasks with learners of different proficiency levels.

\section{Acknowledgements}

This research is partly supported by the Ratchadaphiseksomphot Endowment Fund of Chulalongkorn University

(RES560530083-HS).

\section{References}

Andersen, Roger. 1991. Developmental sequences: The emergence of aspect marking in second language acquisition. In Crosscurrents in Second Language Acquisition and Linguistic Theories, edited by Tom Huebner and Charles A. Ferguson, pp. 305-324. Amsterdam: Benjamins.

Andersen, Roger and Yasuhiro Shirai. 1994. Discourse motivations for some cognitive acquisition principles. Studies in Second Language Acquisition 16.1: 135-156.

Ayoun, Dalila and Maximo Rafael Salaberry. 2008. Acquisition of English Tense-Aspect morphology by advanced French instructed learners. Language Learning 58.3: 555-595.

Bardovi-Harlig, Kathleen. 2000. Tense and Aspect in Second Language Acquisition: Form, Meaning, and Use. Oxford: Blackwell.

Bardovi-Harlig, Kathleen and Anna Bergström. 1996. The acquisition of tense and aspect in SLA and FLL: A study of learner narratives in English 
(SL) and French (FL). Canadian

Modern Language Review 52: 308-330.

Bardovi-Harlig, Kathleen and Dudley W. Reynolds. 1995. The role of lexical aspect in the acquisition of tense and aspect. TESOL Quarterly 29.1: 107 131.

Bloom, Lois, Karin Lifter and JeremieHafitz. 1980. Semantics of verbs and the development of verb inflection in child language. Language 56: 386-412.

Bonilla, Carrie. 2008. Review of task conditions in L2 Spanish acquisition of tense-aspect morphology. Unpublished Ms., Department of Linguistics, University of Pittsburgh.

Brown, Roger. 1973. A First Language. Cambridge, MA: Harvard University Press.

Collins, Laura. 2002. The roles of L1 influence and lexical aspect in the acquisition of temporal morphology. Language Learning 52.1: 43-94.

---. 2004. The particulars on universals: A comparison of the acquisition of tense aspect morphology among Japaneseand French-speaking learners of English. The Canadian Modern Language Review/La Revue Canadienne des Languesvivantes. 61.2: 251-274.

Comrie, Bernard. 1976. Aspect. Cambridge: Cambridge University Press.

---. 1985. Tense. Cambridge: Cambridge University Press.
Francis, Winthrop Nelson and Henry Kucera. 1982. Frequency Analysis of English Usage: Lexicon and Grammar. Boston: Houghton Mifflin.

Giacalone Ramat, Anna. 1995. Tense and aspect in learner Italian. In Temporal Reference, Aspect and Actionality 2: Typological Perspectives, eds. by Pier Marco Bertinetto, ValentinaBianchi, Östen Dahl and Mario Squartini, pp. 289-309. Torino: Rosenberg and Sellier.

Housen, Alex. 2000. Verb semantics and the acquisition of tense-aspect in L2 English. StudiaLinguistica 54.2: 249 259.

---. 2002. A corpus-based study of the L2 acquisition of the English verb system. In Computer Learner Corpora, Second Language Acquisition and Foreign Language Teaching, edited by Sylviane Granger, Joseph Hung and Stephanie Petch-Tyson, pp. 77-116. Amsterdam/Philadelphia: John Benjamins.

Klein, Wolfgang. 1995. The acquisition of English. In The Acquisition of Temporality in a Second Language, ed. by Rainer Dietrich, Wolfgang Klein and Colette Noyau, pp. 31-70. Amsterdam/Philadelphia: John Benjamins.

---. 2010. How time is encoded. In The Expression of Time, eds. by Wolfgang Klein and Ping Li, pp. 39-81. Berlin: Mouton de Gruyter.

Lee, EunHee and Hae-Young Kim. 2007. On crosslinguistic variations in imperfective aspect: The case of L2 Korean. Language Learning 57: 651-685. 
Lyons, John. 1995. Linguistic Semantics: An Introduction. Cambridge: Cambridge University Press.

Malayamonthon, Chartsarut. 1998. Communicative Strategies in Upper Secondary School Students Written English (กลวิธสื่อสารในการเขียนเรียงควา ภาษาอังกฤษของนักเรียนชั้นมัธยมศึกษาตอนปลาย). M.A. thesis. Thammasat University, Bangkok.

Mourelatos, Alexander. 1981. Events, processes, states. In Syntax and semantics: Tense and aspect, eds. By Philip Tedeschi and Annie Zaenen, pp. 191-212. New York: Academic Press.

Noochoochai, Ponlasit. 1978. Temporal aspect in Thai and English. Doctoral dissertation, New York University, New York.

Robinson, Richard. 1990. The primacy of aspect: Aspectual marking in English interlanguage. Studies in Second Language Acquisition 12: 315-330.

Shirai, Yasuhiro. 2010.Temporality in first and second language acquisition. In The Expression of Time, edited by Wolfgang Klein and Ping Li, pp. 167 193. Berlin: Mouton de Gruyter.

Shirai, Yasuhiro and Roger Andersen. 1995. The Acquisition of Tense-Aspect Morphology: A Prototype Account. Language 71.4: 743-762.
Shirai, Yasuhiro and Atsuko Kurono. 1998. The acquisition of tense-aspect marking in Japanese as a second language. Language Learning 48: 245 279.

Smith, Carlota S. 1997. The Parameter of Aspect. $2^{\text {nd }}$ ed. Dordrecht: Kluwer Academic Publishers.

Suwattee, Duangduen. 1971. A linguistic analysis of difficulties in the English verbal system encountered by native speakers of Thai. Doctoral dissertation, University of North Carolina at Chapel Hill, Chapel Hill.

Tawilapakul, Upsorn. 2003. The use of English tenses by Thai university students. M.A. thesis, Thammasat University, Bangkok.

Vendler, Zeno. 1967. Verbs and times. In Semantics: Critical concepts in linguistics, edited by Javier Gutierrez Rexach (2003), pp. 7-22. London and New York: Routledge.

Wolfram, Walt. 1985. Variability in tense marking: A case for the obvious. Language Learning 35.2: 229-253.

Wolfram, Walt and Deborah Hatfield. 1984. Tense marking in second language learning: Patterns of spoken and written English in a Vietnamese community. Final Report, National Institute of Education Grant no. NIE-G 83-0035. 


\section{Appendix A: target verbs for simple past tense}

\begin{tabular}{|c|c|}
\hline $\begin{array}{l}\text { States } \\
(15 \text { tokens })\end{array}$ & $\begin{array}{l}\text { 1. be }(\mathrm{x} 6) \text { 2. want }(\mathrm{x} 2) \text { 3. believe } 4 \text {. think } 5 . \text { look } 6 \text {. understand } \\
\text { 7. prevent } \\
\text { 8. tell } 9 \text {. have }\end{array}$ \\
\hline $\begin{array}{l}\text { Activities } \\
\text { (6 tokens) }\end{array}$ & 1. beg 2. look around 3. wait 4 . stare 5 . sit 6 . share \\
\hline $\begin{array}{l}\text { Telics } \\
\text { (27 tokens) }\end{array}$ & 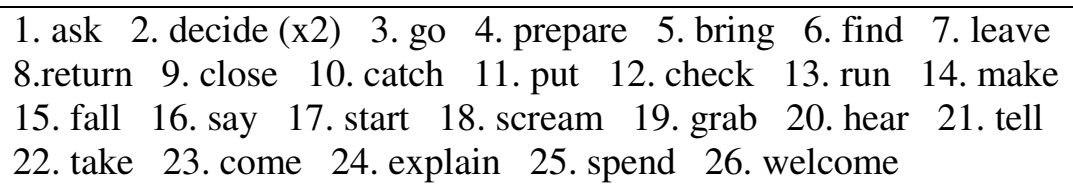 \\
\hline
\end{tabular}

\section{Appendix B: the cloze test (Ayoun and Salaberry 2008)}

This is the story Kevin told me once: "I ___ (to walk) one night. It (to be) bitterly cold, around Christmas time. I __ (to just want) to clear my head. Suddenly, there (to be) a man across the street from the main store. He (to call out) to me. $\mathrm{He}$ _ (to ask) for money to get something to eat. But I (not to want) to be bothered and I ___ (not to believe) him anyway. I___ (to think) that he money to drink or smoke. But he ___ (to look) hungry, so I (to some food instead. I (to go) upstairs and (to prepare) him a sandwich and some soup. When it (to be) ready, I (to bring) it outside to him but he (to disappear). I ___ (to look around) for a few seconds but I (not to find) him. So I (to leave) everything outside and (to return quickly) home. A few minutes later, as I (to close) the curtains from my living room window, I (to catch) a glimpse of that old man: he (to put) the food under his dirty long coat, he (to check hastily) to make sure that no one (to watch) him and he with a slight limp on his left leg. I ___ (not to understand) why he (to run away), me to return, so I ___ (to decide) to follow him. It limp ___ (to prevent) him from going very fast. He (to be) pretty easy, because his narrow back streets I ___ (never to venture) into. The night (to make) several turns into rain) and like I___ (to say), it start) to penetrate me. What jumping back when a hand anyone come behind me. $\mathrm{He}$ (to be) extremely cold. An uneasy feeling (to fall), it _ (to (to tell) me to follow him. He I (to do) here? "No!" I (to scream suddenly), (to grab) my shoulder from behind. I ___ (not to hear) several other homeless people (to stare) at me with a smile and laughing eyes. He cold, you (to tell) that these people (to take) me to an abandoned basement where share usually) whatever they (to have). Kevin (to come often) here, that they (to explain) that he spend) the best Christmas eve with these homeless people who he __ (to be) their long time friend. Since that night, we (to welcome) him as if Christmas eve with some homeless people. We (to listen attentively) to their stories, we (to stay up) all night with them, and the feeling (to remain) the same: sad but also joy. 